\title{
Empirical Estimates for how Changes in China's Foreign Reserves Are Hurting Chinese Exports and Helping US Exports
}

\author{
Jonathan E. Leightner ${ }^{1}$ \\ ${ }^{1}$ Hull College of Business, AllGood Hall, Summerville Campus, Augusta University, $112015^{\text {th }}$ Street, Augusta, \\ Georgia 30912, USA \\ Correspondence: Jonathan E. Leightner, Ph.D., Full Professor of Economics, Hull College of Business, AllGood Hall, \\ Summerville Campus, Augusta University, $112015^{\text {th }}$ Street, Augusta, Georgia 30912, USA. Tel: 1-706-667-4545.
}

Received: February 5, 2018

Accepted: February 26, $2018 \quad$ Online Published: March 5, 2018

doi:10.5430/ijfr.v9n2p55

URL: https://doi.org/10.5430/ijfr.v9n2p55

\begin{abstract}
This paper estimates the change in China's exports and the change in US exports due to a one dollar increase in China's foreign reserves. The statistical technique used produces reduced form estimates that capture the influence of omitted variables without having to construct and estimate complex structural models. I find that in August 2000 China's accumulation of 621 million dollars of foreign reserves is correlated with China's exports increasing by 151 million and the US's exports falling by 628 million dollars. In contrast, in November 2016, China spending 69 billion dollars of its foreign reserves supporting the value of the yuan is correlated with China's exports falling by 4.77 billion and the US's exports rising by 2.42 billion. Donald Trump's accusation that China is suppressing the yuan exchange rate to help Chinese exports at the expense of US exports did not fit the facts between August 11, 2015 and December 31, 2016.
\end{abstract}

Keywords: China's trade surplus, the US's trade deficit, fixed exchange rates, currency manipulation

\section{Introduction}

When campaigning for the US presidency in 2016, Donald Trump repeatedly promised to label China a "currency manipulator" on his first day in office. Although Trump did not keep that promise, he has continued to pressure China to reduce her trade surplus with the USA. Trump seems to believe that China has been suppressing the value of the Chinese yuan in order to make China's exports cheaper which helps them to sell, to the detriment of the USA. An investigation into Trump's accusations should start with an examination of China's holdings of foreign reserves. If China's foreign reserves are steadily rising, then the Chinese government might be printing more yuan and selling it for US dollars (or other foreign reserves) in order to keep the value of the yuan artificially low. However, if China's foreign reserves are falling, then China might be using her foreign reserves to purchase back surplus Chinese yuan in an effort to keep the value of the yuan from plummeting. Artificially keeping the value of the yuan up hurts Chinese exports and helps US exports.

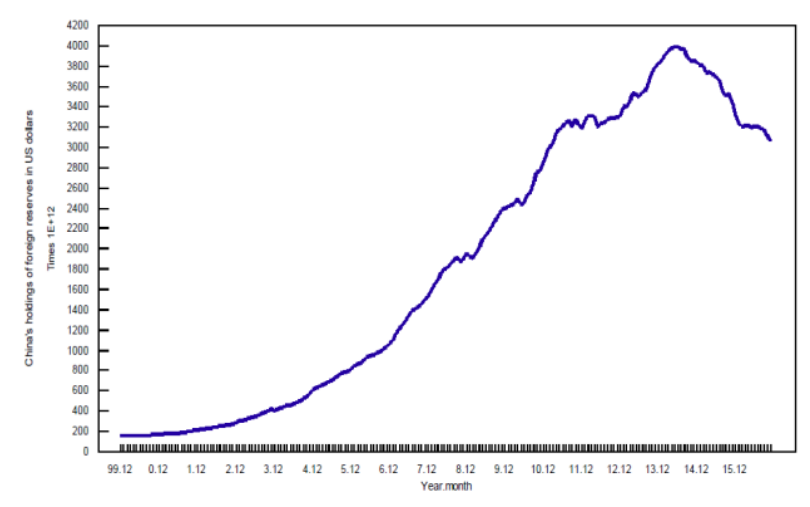

Figure 1. China's holding of foreigh reserves in US Dollars 
In October 2006, China's holdings of foreign reserves hit the one trillion US dollar mark. Between October 2006 and June 20

14, China's holdings of foreign reserves climbed from one trillion US dollars to 3.99 trillion dollars. During this time frame, the Chinese government was artificially suppressing the value of the Chinese yuan which would help Chinese exports and hurt US exports, ceteris paribus. However, as Figure 1 shows, starting in July 2014, China's holdings of foreign reserves have been on a downward trend. Indeed, by December 2016, China's holdings of foreign reserves had fallen to 3.01 trillion US dollars. In other words, between July 2014 and December 2016, China spent (Note 1) slightly less than a trillion dollars, or one fourth of her total, reserves.

A significant portion of the fall in China's foreign reserves between July 2014 and August 2015 could have been due to the Chinese going on a buying spree for foreign assets (Leightner, 2017). However, after August 11, 2015 the Chinese government was actively supporting the value of the Chinese yuan in an effort to keep its value from plummeting; hurting Chinese exports and helping US exports; contrary to Donald Trump's accusations.

This paper provides estimates of the change in China's exports and the change in US exports due to a one dollar increase in China's foreign reserves. The analysis is then repeated using net exports (exports minus imports). I find that in August 2000 China's accumulation of 621 million dollars of foreign reserves is correlated with China's exports increasing by 151 million and the US's exports falling by 628 million dollars. In contrast, in November 2016, China spending 69 billion dollars of its foreign reserves supporting the value of the yuan is correlated with China's exports falling by 4.77 billion and the US's exports rising by 2.42 billion. The remainder of the paper is structured as follows. Section II of the paper explains what happened on August 11, 2015 and why China shifted from accumulating to spending foreign reserves. Section III discusses data, modelling, and estimation issues. Section IV presents the empirical results, and Section V concludes.

\section{What Happened on August 11, 2015 and Its Aftermath}

On May 26, 2015 the International Monetary Fund (IMF) publically announced that China's yuan was finally at fair market value. On that day, 6.2075 yuan traded for one US dollar. The IMF also strongly encouraged China to, as quickly as possible, eliminate its exchange rate controls (Magnier and Kazer, 2015). Prior to August 11, 2015 the People's Bank of China (PBOC) collected yuan per dollar quotes from entities involved in the foreign exchange market, like state owned banks. The PBOC then set a "central parity" or "midpoint" exchange rate based on the average of these quotes. If the actual exchange rate rose more than two percent over the set midpoint, the PBOC would sell yuan in order to bring its price down, accumulating foreign currencies (reserves) in the process. If the actual exchange rate fell more than two percent under the midpoint, the PBOC would buy yuan to increase its value, spending foreign reserves in the process.

In theory, it is the market makers, not the central bank, which set the midpoint and thus the trading band. In practice, the PBOC gets market makers to submit rates that will yield its preferred midpoint, irrespective of market sentiment (state-owned banks are pliant, after all) ("Battle of Midpoint," 2015).

China changed this process on August 11, 2015; however, before that date, China's stock market plummeted.

In 2014 the Shanghai stock market gained 37 percent, making it the world's best performing major stock market (Hong, 2014). By June 14, 2015, the Shanghai Stock Index was up 136 percent for the past 12 months and 51 percent since the beginning of the year. The Shanghai stock market started falling on June 15, 2015. By July 9, 2015 the Shanghai Index had lost 32 percent of its value or US\$ 3.5 trillion of value (Hong and Wei, 2015). By the end of July 2015, US\$ 5 trillion of value had been erased from China's stock market (Wei, 2015). No longer trusting the Shanghai stock exchange, many Chinese wanted to move their assets abroad to safer locations, like the USA, which put downward pressure on the yuan.

On August 11, 2015, the People's Bank of China (PBOC) informed the public that it was changing how the yuan's central parity rate would be set; specifically, the new procedure would set each day's central parity rate as the previous day's closing value. The PBOC continued to use this new procedure for the remainder of 2015 (Trivedi, 2016). If one views exchange rates as lying along a continuum between fixed and flexible, this new procedure was an extremely important move towards a more flexible exchange rate. However, "the new market-determined midpoint immediately fell by $1.9 \%$, the biggest single-day drop in the yuan's modern history." The next day, August 12, 2015, the yuan fell again. On that day the PBOC ordered China's state owned banks to use their dollar reserves to purchase yuan, in order to keep the yuan from falling further ("Battle of Midpoint," 2015).

The Economist ("Battle of Midpoint," 2015) believes that China adopted the new central parity method because China wanted the International Monetary Fund (IMF) to include the yuan in the IMF's listing of global reserve 
currencies (a status China received in November 2015) and the week before the IMF had "hinted" that the yuan continued to be too heavily controlled to be included. The Economist also believes that China spent foreign reserves to keep the yuan from falling further because China was scared that a sustained devaluation would lead to a surge of capital flight out of China causing a vicious downward spiral in the value of the yuan ("Battle of Midpoint," 2015), a downward spiral similar to the June - July, 2015 collapse of China's stock market (Wei and Trivedi, 2015).

Indeed, the international currency market did bet that China would devalue the yuan even more as evidenced by the cost of insuring (hedging) against an additional fall in the value of the yuan surging "from US\$ 30,500 per US\$ 100 million to US\$ 1.7 million" in August 2015 (Cui, Trivedi, and Albanese, 2015). Furthermore, between August 11, 2015 and January 2017, the Chinese government imposed progressively stronger capital controls in an effort to arrest the fall in the value of the yuan. These measures included (1) reducing the amount of yuan available to Hong Kong banks and driving up the interest cost of accessing yuan in Hong Kong, (2) obstructing the repatriation of earnings by foreign companies located in China by making repatriation documentation onerous, (3) banning overseas investments made in yuan, and (4) "imposing reserve requirements on Hong Kong-based yuan deposits parked by offshore banks at the Bank of China Ltd. Unit" which decreased the amount of yuan available to Hong Kong banks by an amount equal to US\$ 23 billion (Wei, January 28, 2016). Moreover, Xi's government imposed limits on the amount of money that can be withdrawn from foreign ATMs by Chinese travelling abroad. Xi's government also sternly warned banks to check all foreign currency transactions to make sure that they are legitimate and justifiable. Bank leaders were told that, if foreign currency transactions increased, they would be called before the government where they would have to give a thorough accounting. The banks understood that the government wanted the amount of foreign currency transactions to significantly decline. China's banks responded by delaying the process of supplying foreign currency via asking for additional documentation many times (Wei Gu and Yap, 2016). Multinational companies used to be able to "'sweep' US\$ 50 million worth of yuan or dollars in or out of China with minimal documentation. Now the cap is the equivalent of US\$ 5 million" (Areddy and Wei, 2016). China has also started to limit foreign purchases by Chinese companies (Wei, November 26-27, 2016).

Chinese state banks purchasing yuan on January 8, 2016 (a Friday) and on January 11, 2016 (the next Monday) "sent the cost of borrowing yuan overnight soaring past $66 \%$ by Tuesday [Monday had set a new record at $13.4 \%$ ], making it prohibitively expensive for investors to finance bets against the currency, known as a short sale" (Trivedi and Law, 2016). "Yuan short sellers would borrow yuan, sell it for dollars, and then when the yuan fell in value, trade in the dollars for yuan to pay off the debt while pocketing the difference in the original and final exchange rates" (Leightner, 2017). China's state banks purchasing yuan increased the demand for the yuan which drove up the value of the yuan by $1.8 \%$ causing short sellers to lose money (Trivedi and Law, 2016). On September 12, 2016, the PBOC again drove up the cost of borrowing yuan to 5.52 percent (Vaishampayan and Wei, 2016). At one point in January 2017, the overnight interest rate to borrow yuan offshore "reached an incredible 105\%" (Mauldin, 2017). The PBOC wants the yuan to be unpredictable because that discourages speculation (Wei, January 15, 2016).

Contrary to Trump's allegations, China is now supporting, not suppressing, the value of the yuan. Although Trump might point to the fact that the yuan has fallen in value by more than ten percent against the US dollar and by seven percent against a basket of China's major trading partners' currencies since August 2015 (Wei, 2017), the litmus test for an undervalued currency is an increase in foreign reserves (not a fall in the exchange rate), and China's foreign reserves fell (the opposite of rising) by almost 547 billion US dollars between August 2015 and December 2016 and by almost a trillion US dollars between June 2014 and December 2016. If China had not been buying up surplus yuan since August 12, 2015 and if China had not imposed strong controls limiting the movement of capital out of China, then the Chinese yuan would have fallen in value even more than it did.

\section{Data, Modelling, and Estimation Issues}

Data on China's foreign reserves was downloaded from China's State Administration of Foreign Exchange Website, and data on China exports and imports was obtained from China's National Bureau of Statistics website. Data on US exports and imports was downloaded from the US Census website. All data series are monthly, starting in December 1999 and ending in November 2016. China publishes the total dollar amount of its foreign reserves, but does not tell what percent of those reserves are held in dollars, euros, yen, pounds, etc. Historically China has held more than half of its foreign reserves in US dollars. Given limitations to the data available, there is no good way to adjust this paper's analysis for changes in the allocation of China's foreign reserves between different currencies.

Currency speculators watch the foreign reserves of countries, and when those foreign reserves fall noticeably, speculators tend to expect the value of the currency to fall causing the speculators to sell the currency which puts downward pressure on its value, making the government's defense of the currency even harder. Expectations are 
self-fulfilling, and they can lead to a vicious downward spiral. Knowing this, some governments defend the value of their currencies in ways that do not immediately cause a depletion of foreign reserves. For example, some governments defend by purchasing forward contracts which do not immediately affect official foreign reserves. When China's foreign reserves fell less in September 2015 than in August 2015, J.P. Morgan suspected that the People's Bank of China was "window-dressing" its foreign reserves by using forward interventions to hide actual declines (Cui, 2015). The International Monetary Fund (IMF) became suspicious that China was taking similar actions in February 2016 (Wei, March 22, 2016). Likewise, when China's foreign reserves increased by US\$ 10.26 billion in March 2016, some currency experts wondered if China was including yuan-denominated assets (which were outside of China) in its "foreign" reserves so that China could report a rise in foreign reserves instead of the fall that was expected. Supposedly evidence backing that concern exists (Chang, 2016). Since there is no good way to adjust China's official foreign reserves for these types of "window-dressings," this paper accepts the Chinese data at face value.

To use traditional regression procedures to estimate the change in the US's exports due to a one dollar increase in China's holdings of foreign reserves, $d$ (US exports) $/ d$ (China's reserves), a researcher would have to build a structural model that included all the forces that affect the supply and demand for the US dollar, the Chinese yuan, and US exports. Such a model would need to explain foreign investment, remittances, tourism, interest rates, expectations, etc. for both the US and China. Furthermore, such a model would have to include everything that affects comparative advantage including resource endowments, technology, and input prices. Similar models would have to be built to estimate $d$ (US net exports) $/ d$ (China's reserves), $d$ (China's exports) $/ d$ (China's reserves), and $d$ (China's net exports)/ $d$ (China's reserves). Once the model was constructed and all the equations estimated, it could then be solved for the relationships listed above, which are "total derivatives." The construction and estimation of such models that accurately include every possible force that could affect exports, imports and foreign reserves are impossible.

Fortunately there are ways to estimate total derivatives that capture the effects of omitted variables without having to construct and estimate entire structural models (Inoue, Lafaye de Micheaux, and Leightner, 2016). If a researcher estimates equation (1) while ignoring equation (2), the resulting estimate of $\beta_{1}$ is a constant when in truth $\beta_{1}$ varies with $\mathrm{q}_{\mathrm{t}}$. (Note 2) This constitutes an "omitted variable" problem where " $\mathrm{q}_{\mathrm{t}}$ " represents the combined influence of all omitted variables plus any random variation in $\beta_{1}$ itself.

$$
\begin{gathered}
\mathrm{Y}_{\mathrm{t}}=\alpha_{0}+\beta_{1} \mathrm{X}_{\mathrm{t}}+u \\
\beta_{1}=\alpha_{1}+\alpha_{2} \mathrm{q}_{\mathrm{t}}
\end{gathered}
$$

One convenient way to model the omitted variable problem is to combine equations (1) and (2) to produce equation (3).

$$
\mathrm{Y}_{\mathrm{t}}=\alpha_{0}+\alpha_{1} \mathrm{X}_{\mathrm{t}}+\alpha_{2} \mathrm{X}_{\mathrm{t}} \mathrm{q}_{\mathrm{t}}+u_{\mathrm{t}}
$$

Equation (7) can be derived from equation (3) as shown below (Leightner, 2015, 2010a, and 2010b; Inoue et al, 2016; and Leightner and Inoue 2012b).

$$
\begin{aligned}
& \left(d \mathrm{Y}_{\mathrm{t}} / d \mathrm{X}_{\mathrm{t}}\right)^{\text {True }}=\alpha_{1}+\alpha_{2} \mathrm{q}_{\mathrm{t}} \quad \text { Derivative of (3) } \\
& \mathrm{Y}_{\mathrm{t}} / \mathrm{X}_{\mathrm{t}}=\alpha_{0} / \mathrm{X}_{\mathrm{t}}+\alpha_{1}+\alpha_{2} \mathrm{q}_{\mathrm{t}}+u_{t} / \mathrm{X}_{\mathrm{t}} \quad \text { (3) divided by } \mathrm{X} \\
& \alpha_{1}+\alpha_{2} \mathrm{q}_{\mathrm{t}}=\mathrm{Y}_{\mathrm{t}} / \mathrm{X}_{\mathrm{t}}-\alpha_{0} / \mathrm{X}_{\mathrm{t}}-u_{\mathrm{t}} / \mathrm{X}_{\mathrm{t}} \quad \text { (5) rearranged } \\
& \left(d \mathrm{Y}_{\mathrm{t}} / d \mathrm{X}_{\mathrm{t}}\right)^{\text {True }}=\mathrm{Y}_{\mathrm{t}} / \mathrm{X}_{\mathrm{t}}-\alpha_{0} / \mathrm{X}_{\mathrm{t}}-u_{t} / \mathrm{X}_{\mathrm{t}} \quad \text { From (4) and (6) }
\end{aligned}
$$

If an estimate for $\alpha_{0}$ could be found, then it could be used to calculate a separate slope estimate for each observation using equation (8). The error due to such a procedure is shown in equation (9). The $u_{t} / X_{t}$ term in equation (9) should be extremely small because random error, $u_{t}$, is usually tiny relative to the size of $X_{t}$, making $u_{t} / X_{t}$ even smaller. This implies that the accuracy of calculating a separate slope estimate for each observation using equation (8) depends primarily upon the accuracy of the $\alpha_{0}$ estimate.

$$
\begin{gathered}
\left(d \mathrm{Y}_{\mathrm{t}} / d \mathrm{X}_{\mathrm{t}}\right)^{\wedge}=\mathrm{Y}_{\mathrm{t}} / \mathrm{X}_{\mathrm{t}}-\alpha_{0} \wedge / \mathrm{X}_{\mathrm{t}} \\
\left(d \mathrm{Y}_{\mathrm{t}} / d \mathrm{X}_{\mathrm{t}}\right)^{\text {True }}-\left(d \mathrm{Y}_{\mathrm{t}} / d \mathrm{X}_{\mathrm{t}}\right)^{\wedge}=\left(\alpha_{0} \wedge-\alpha_{0}\right) / \mathrm{X}_{\mathrm{t}}-u_{\mathrm{t}} / \mathrm{X}_{\mathrm{t}} \quad \text { From (7) and (8) }
\end{gathered}
$$

Inoue et. al. (2016) explore three ways to obtain an estimate for $\alpha_{0}$ : they are (I) using Ordinary Least Squares to estimate equation (1), (II) using Generalized Least Squares to estimate equation (1), and (III) using Bi-Directional Reiterative Truncated Projected Least Squares (BD-RTPLS) which produces separate slope estimates for layers of the data by peeling the data down layer by layer and then peeling the data up after which equation (10) is used with the resulting layer slopes to estimate $\alpha_{0}$. Leightner and Inoue (2012b) explain the math that underlies BD-RTPLS. 


$$
\left(d \mathrm{Y}_{\mathrm{t}} / d \mathrm{X}_{\mathrm{t}}\right)^{\wedge}-\mathrm{Y}_{\mathrm{t}} / \mathrm{X}_{\mathrm{t}}=-\alpha_{0} \wedge / \mathrm{X}_{\mathrm{t}} \quad \text { (8) rearranged }
$$

Inoue et. al. (2016) show that when the omitted variable problem is ignored by estimating equation (1) using OLS, the resulting estimate for $\beta_{1}$ is approximately $\alpha_{1}+\alpha_{2} \mathrm{E}\left[\mathrm{q}_{\mathrm{t}}\right]$ which leaves an "error" for the $\mathrm{t}=\mathrm{i}^{\text {th }}$ observation of approximately $\alpha_{2} \mathrm{X}_{\mathrm{i}}\left(\mathrm{q}_{\mathrm{i}}-\mathrm{E}\left[\mathrm{q}_{\mathrm{i}}\right]\right)+u_{\mathrm{i}}$. The three methods of correcting for the omitted variables problem explored by Inoue et. al. (2016) would be better than ignoring the omitted variables problem if $\left|\left(\alpha_{0} \wedge-\alpha_{0}\right) / \mathrm{X}_{\mathrm{i}}-u_{\mathrm{i}} / \mathrm{X}_{\mathrm{i}}\right|$ is less than $\left|\alpha_{2}\left\{q_{i}-E\left[q_{i}\right]\right\}\right|$. Aitken (1935) implies that the GLS estimate of $\alpha_{0}$ will be the Best Linear Unbiased Estimate (BLUE) if the $\mathrm{q}_{\mathrm{i}} \mathrm{s}$ are i.i.d. $\mathrm{N}\left(\mu_{\mathrm{q}}, \sigma_{\mathrm{q}}{ }^{2}\right)$ because GLS is BLUE for heteroscedastic models and Inoue et.al (2016) show that equation (3) is a heteroscedastic model if $\mathrm{q}_{\mathrm{i}}$ is unknown.

Inoue et.al (2016) test the three methods using simulations (Leightner 2015 and Leightner and Inoue 2012b also provide simulation tests but solely for BD-RTPLS). Inoue et.al. (2016) run sets of 5,000 simulations each for the 27 combinations of 100 observations, 250 observations, and 500 observations with the omitted variable making a 1,000 percent difference to the slope, a 100 percent difference to the slope, and a 10 percent difference to the slope, and with random error being zero, one percent, and ten percent. Inoue et.al. (2016) gives the name "Variable Slope Ordinary Least Squares" (VSOLS) to the process of using OLS to estimate $\alpha_{0}$ which is then plugged into equation (8) to generate a separate slope estimate for each observation and the name "Variable Slope Generalized Least Squares" (VSGLS) to the process using GLS to estimate $\alpha_{0}$ which is then plugged into equation (8).

VSGLS and BD-RTPLS noticeably out performed VSOLS in all simulations. VSGLS and BD-RTPLS out performed using OLS while ignoring the omitted variables problem except for the case where the omitted variable makes only a ten percent difference to the slope and random error is ten percent. When the importance of the omitted variable was 100 times as big as random error, using OLS while ignoring omitted variables produced approximately 35 times the error of both VSGLS and BD-RTPLS. When the importance of the omitted variable was 10 times as big as random error, then using OLS while ignoring omitted variables produced approximately 3.8 times the error of both VSGLS and BD-RTPLS. When there was no random error, then BD-RTPLS produced less than half the error of VSGLS. (Note 3) This last result implies that, since VSGLS is BLUE, BD-RTPLS must be better than BLUE when there is no random error which is reasonable if BD-RTPLS is better at capturing non-linear aspects of the data. Published applications of BD-RTPLS include Leightner, 2015, 2013, 2011a, 2011b, 2010a, 2010b, 2008, 2007, 2005a, 2005b, 2002 and Leightner and Inoue, 2012a, 2012b, 2009, 2008a, 2008b, and 2007. The next section of the paper uses BD-RTPLS to estimate the effects of China's holdings of foreign reserves on China's exports, China's net exports, US exports, and US net exports.

\section{The Empirical Results}

Table 1. Estimates and 99\% confidence intervals

\begin{tabular}{|c|c|c|c|c|c|c|c|c|c|c|c|c|}
\hline & 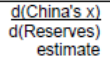 & confidence & interval & $\frac{\mathrm{d}(\text { China } x-\mathrm{m})}{\mathrm{d}\left(\begin{array}{r}\text { Reserves) } \\
\text { estimate }\end{array}\right.}$ & confidence & interval & $\begin{array}{r}\frac{\mathrm{d}(\text { USA's } \mathrm{x})}{\mathrm{d}(\text { Reserves) }} \\
\text { estimate }\end{array}$ & confidence & interval & $\begin{array}{r}\frac{d(\text { (USA } x-m)}{d(\text { Reserves) }} \\
\text { estimate }\end{array}$ & confidence & interval \\
\hline April 2014 & 0.051 & 0.034 & 0.060 & 0.021 & 0.010 & 0.029 & -0.024 & -0.027 & -0.021 & -0.026 & -0.027 & -0.020 \\
\hline May 2014 & 0.053 & 0.046 & 0.058 & 0.025 & 0.017 & 0.029 & -0.023 & -0.025 & -0.022 & -0.025 & -0.028 & -0.022 \\
\hline June 2014 & 0.051 & 0.049 & 0.059 & 0.024 & 0.020 & 0.030 & -0.023 & -0.024 & -0.022 & -0.024 & -0.027 & -0.023 \\
\hline July 2014 & 0.058 & 0.050 & 0.061 & 0.028 & 0.022 & 0.029 & -0.024 & -0.025 & -0.022 & -0.027 & -0.028 & -0.023 \\
\hline August 2014 & 0.056 & 0.051 & 0.062 & 0.029 & 0.023 & 0.030 & -0.023 & -0.025 & -0.021 & -0.024 & -0.028 & -0.023 \\
\hline September 2014 & 0.059 & 0.056 & 0.060 & 0.024 & 0.024 & 0.032 & -0.025 & -0.026 & -0.022 & -0.027 & -0.028 & -0.023 \\
\hline October 2014 & 0.058 & 0.055 & 0.063 & 0.028 & 0.024 & 0.032 & -0.022 & -0.026 & -0.022 & -0.026 & -0.028 & -0.023 \\
\hline November 2014 & 0.059 & 0.055 & 0.063 & 0.031 & 0.024 & 0.034 & -0.025 & -0.029 & -0.021 & -0.024 & -0.028 & -0.023 \\
\hline December 2014 & 0.063 & 0.048 & 0.066 & 0.029 & 0.028 & 0.034 & -0.025 & -0.031 & -0.021 & -0.025 & -0.028 & -0.021 \\
\hline January 2015 & 0.057 & 0.041 & 0.067 & 0.032 & 0.019 & 0.039 & -0.028 & -0.030 & -0.023 & -0.025 & -0.028 & -0.021 \\
\hline February 2015 & 0.049 & 0.040 & 0.065 & 0.033 & 0.018 & 0.038 & -0.029 & -0.030 & -0.024 & -0.021 & -0.028 & -0.021 \\
\hline March 2015 & 0.043 & 0.042 & 0.060 & 0.018 & 0.018 & 0.039 & -0.026 & -0.030 & -0.025 & -0.027 & -0.028 & -0.021 \\
\hline April 2015 & 0.051 & 0.042 & 0.060 & 0.026 & 0.018 & 0.038 & -0.027 & -0.029 & -0.025 & -0.026 & -0.029 & -0.021 \\
\hline May 2015 & 0.055 & 0.043 & 0.062 & 0.033 & 0.018 & 0.037 & -0.027 & -0.029 & -0.025 & -0.025 & -0.029 & -0.025 \\
\hline June 2015 & 0.056 & 0.051 & 0.061 & 0.030 & 0.025 & 0.036 & -0.027 & -0.030 & -0.026 & -0.028 & -0.030 & -0.025 \\
\hline July 2015 & 0.058 & 0.053 & 0.063 & 0.029 & 0.028 & 0.037 & -0.029 & -0.031 & -0.026 & -0.029 & -0.030 & -0.025 \\
\hline August 2015 & 0.060 & 0.055 & 0.063 & 0.035 & 0.028 & 0.038 & -0.030 & -0.031 & -0.026 & -0.029 & -0.029 & -0.028 \\
\hline September 2015 & 0.063 & 0.057 & 0.064 & 0.035 & 0.030 & 0.038 & -0.030 & -0.032 & -0.027 & -0.029 & -0.029 & -0.028 \\
\hline October 2015 & 0.059 & 0.055 & 0.071 & 0.036 & 0.034 & 0.037 & -0.028 & -0.033 & -0.027 & -0.028 & -0.029 & -0.028 \\
\hline November 2015 & 0.062 & 0.055 & 0.071 & 0.034 & 0.033 & 0.039 & -0.032 & -0.038 & -0.026 & -0.028 & -0.029 & -0.028 \\
\hline December 2015 & 0.072 & 0.043 & 0.075 & 0.037 & 0.030 & 0.041 & -0.033 & -0.039 & -0.027 & -0.029 & -0.029 & -0.028 \\
\hline January 2016 & 0.060 & 0.042 & 0.075 & 0.039 & 0.027 & 0.041 & -0.037 & -0.038 & -0.030 & -0.029 & -0.029 & -0.027 \\
\hline February 2016 & 0.044 & 0.042 & 0.074 & 0.030 & 0.027 & 0.041 & -0.036 & -0.038 & -0.031 & -0.028 & -0.029 & -0.027 \\
\hline March 2016 & 0.055 & 0.045 & 0.067 & 0.029 & 0.027 & 0.040 & -0.032 & -0.038 & -0.032 & -0.028 & -0.031 & -0.026 \\
\hline April 2016 & 0.058 & 0.045 & 0.068 & 0.034 & 0.028 & 0.037 & -0.034 & -0.036 & -0.031 & -0.028 & -0.032 & -0.026 \\
\hline May 2016 & 0.062 & 0.055 & 0.064 & 0.036 & 0.029 & 0.038 & -0.034 & -0.036 & -0.032 & -0.031 & -0.033 & -0.027 \\
\hline June 2016 & 0.061 & 0.058 & 0.065 & 0.035 & 0.034 & 0.037 & -0.032 & -0.036 & -0.032 & -0.031 & -0.034 & -0.028 \\
\hline July 2016 & 0.062 & 0.060 & 0.065 & 0.036 & 0.033 & 0.037 & -0.035 & -0.036 & -0.032 & -0.032 & -0.033 & -0.030 \\
\hline August 2016 & 0.065 & 0.060 & 0.065 & 0.036 & 0.033 & 0.037 & -0.033 & -0.035 & -0.031 & -0.033 & -0.033 & -0.030 \\
\hline September 2016 & 0.063 & 0.060 & 0.068 & 0.033 & 0.033 & 0.037 & -0.033 & -0.036 & -0.032 & -0.030 & -0.034 & -0.030 \\
\hline October 2016 & 0.062 & & & 0.036 & & & -0.032 & & & -0.032 & & \\
\hline November 2016 & 0.069 & & & 0.035 & & & -0.035 & & & -0.034 & & \\
\hline
\end{tabular}




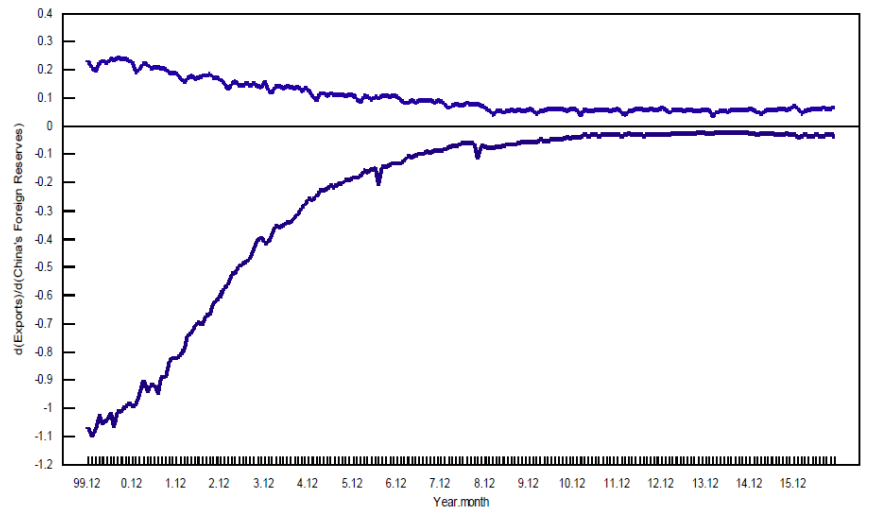

Figure 2. $\mathrm{d}($ Export $) / \mathrm{d}($ China's foreign reserves $)$

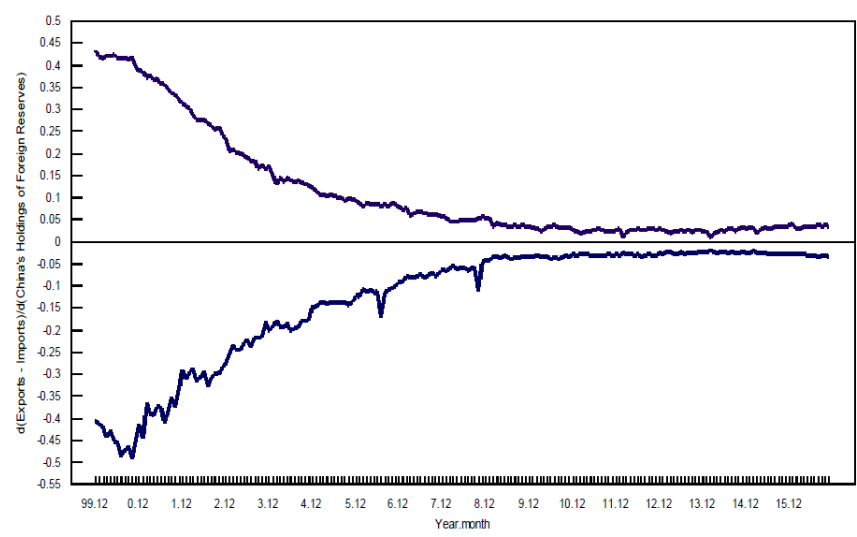

Figure 3. $d$ (Export-import)/d(China's foreign reserves)

Upper line is for China's net export; lower line is for the USA's net export

Figures 2 and 3 depict all the empirical results which stretch from December 1999 through November 2016. Due to space limitations, Table 1 lists only the empirical results for April 2014 through November 2016. Each estimate was based on 203 observations. Ninety nine percent confidence intervals were constructed by using the Central Limit Theorem (Equation 11) applied to a given estimate and the two estimates before and the two estimates after it where " $\mathrm{s}$ " is the standard deviation, " $\mathrm{n}$ " is the number of observations and " $\mathrm{t}$ " is from the Student's T Table. This confidence interval implies that a researcher can be 99 percent confident that the next estimate will lie in that interval if omitted variables fluctuate no more than they recently have fluctuated (Leightner 2015).

$$
\text { confidence interval }=\text { mean } \pm\left(\mathrm{s} / \sqrt{n}_{\mathrm{n}}\right) \mathrm{t}_{\mathrm{n}-1, \alpha / 2}
$$

The maximum value for $d$ (China's Exports)/ $d$ (China's Foreign Reserves) in the data was 0.2438 which occurred in August of 2000. This means that for every dollar that China accumulated as foreign reserves in August 2000, China's exports increased by only 0.2438 dollars. To sustain an export driven growth model via the suppression of the exchange rate by accumulating foreign reserves, a country can never spend the foreign reserves it accumulates (Leightner, 2015). If it ever spends its accumulated foreign reserves, then its exchange rate will rise, ceteris paribus, causing its exports to fall. Thus, in August 2000, China accumulating 621 million US dollars of foreign reserves increased China's exports by only 151.4 million (621 times 0.2438 ) for a net loss of almost 470 million dollars (assuming China sold exports worth 621 million to get those reserves but never uses those reserves). Economics correctly argues that free trade benefits both traders; however, that does not mean that it is good to increase trade beyond what would naturally occur by adding market distortions (like fixing an exchange rate below equilibrium and thus accumulating foreign reserves).

China's loss from accumulating foreign reserves is smaller if one considers China's net exports, exports minus imports, instead of just exports. It is better to consider net exports because Gross Domestic Product (GDP) is 
personal consumption plus investment in tools, equipment and buildings, plus government purchases of final goods and services, plus changes in inventories plus net exports. The maximum value found for $d$ (China's Exports minus Imports)/d (China's Foreign Reserves) was 0.4302 in December 1999, implying that only 43.02 percent of each dollar accumulated was replaced by an increase in net exports. As the top lines in Figures 2 and 3 show, the increase in China's exports and net exports from accumulating an additional dollar of foreign reserves has steadily fallen over time. These results fit with what Leightner (2013 and 2015) found for other countries.

The minimum value found for $d$ (USA's Exports)/ $d$ (China's Foreign Reserves) was -1.1 in January 2000. This number implies that as China accumulated 3.049 billion dollars of foreign reserves in January 2000, the USA's exports fell by 3.354 billion dollars. Again it is better to look at net exports (exports minus imports) because that is what is added to GDP. The minimum value found for $d$ (USA's Exports - Imports)/ $d$ (China's Foreign Reserves) was -0.492 in October 2000. Thus as China accumulated 1252 million US dollars in October 2000, US net exports fell by 616 million dollars (1252 times -0.492). Clearly China accumulating foreign reserves to propel an export driven growth model hurt USA exports and net exports. However it also helped US consumers by suppressing the prices they paid for Chinese goods.

The bottom lines of Figures 2 and 3 show that the damage done to US exporting by China accumulating foreign reserves has noticeably diminished over time. For example, in April 2014 when China accumulated 30.7 billion dollars of foreign reserves, $d$ (USA's Exports - Imports)/ $d$ (China's Foreign Reserves) was -0.026 (see the first line of Table 1), implying that USA net exports fell by only 0.798 billion (30.7 times -0.026); meanwhile, China gained only 0.645 billion of net exports.

Most importantly, Figure 1 shows that China has been spending foreign reserves since June 2014. Furthermore, between August 2015 and December 2016 China spent foreign reserves specifically to support its exchange rate (see section II above), the opposite of Trump's accusation. Consider several specific months. In December 2015, China spent 107.9 billion dollars supporting the Chinese yuan. The numbers in Table 1 imply that that fall in China's foreign reserves was correlated with a 7.77 billion dollar fall in China's exports (107.9 times 0.072), a 3.99 billion dollar fall in China's net exports (107.9 times 0.037), a 3.56 billion increase in US exports (107.9 times 0.033), and a 3.13 billion increase in US net exports (107.9 times 0.029).

Consider the last month for which I have data. In November 2016, China spent 69.06 billion dollars defending the value of the Chinese yuan. The numbers in Table 1 imply that that fall in China's foreign reserves was correlated with a 4.77 billion dollar fall in China's exports (69.06 times 0.069), a 2.42 billion dollar fall in China's net exports (69.06 times 0.035), a 2.42 billion increase in US exports (69.06 times 0.035 ), and a 2.35 billion increase in US net exports (69.06 times 0.034). By spending foreign reserves to keep the yuan from falling, China has been increasing US exports and net exports while reducing China's exports and net exports - the opposite of Trump's accusations.

\section{Conclusion}

The economist's mantra that free trade benefits both traders does not imply that it is helpful to attempt to augment those gains by adding market distortions, like suppressing exchange rates via the accumulation of foreign reserves. The empirical results of this paper show that China's export driven growth model of 1985 to 2007 via the perpetual accumulation of more and more foreign reserves was not worth the cost - in dollar terms China gained much less in exports and net exports than the foreign reserves that they were accumulating and could never spend under that model. Furthermore, while accumulating foreign reserves, China did hurt US exports and net exports.

However, China hurting US exports by accumulating foreign reserves ended in July 2014 when China started spending those reserves. The hurt especially ended when China started to spend foreign reserves to prop up the value of the Chinese yuan, as they have done between August 2015 and December 2016. By multiplying this paper's estimates by each month's change in foreign reserves and summing the results for July 2014 through November 2016, it can be shown that the accumulated increase in US exports total 28.78 billion dollars and the accumulated increase in US net exports totaled 26.90 billion dollars due to changes in China's foreign reserves between July 2014 and November 2016. The corresponding sums for August 2015 to November 2016 are an increase of 19.96 billion dollars of US exports and an increase of 17.81 billion dollars of US net exports due to changes in China's foreign reserves. If Trump wants to increase US exports, then he should be thanking China, not condemning China.

\section{Acknowledgement}

I appreciate the help of Parker Riggs with acquiring the data and setting it up for me. 


\section{References}

Aitken, A. C. (1935). On Least Squares and Linear Combinations of Observations. Proceedings of the Royal Society of Edinburgh, 55, 42-48. https://doi.org/10.1017/S0370164600014346

Areddy, James T., \& Lingling Wei. (2016). China Clamps Down on Exodus of Cash. Wall Street Journal, December 2, B1-B2.

Battle of Midpoint. (2015, August 15). The Economist, 416(8951), 63-64.

Chang, Gordon G. (2016, April 10). Is China Counting Yuan as Forex?. Forbes.

Cui, Carolyn. (2015). China's Yuan Slides on Devaluation Bets. Wall Street Journal, October 24-25, B5.

Cui, Carolyn, Anjani, Trivedi \& Chiara Albanese. (2015). Traders Increase Bets Against Yuan. Wall Street Journal, August 26, C1-C2.

Hong, Shen. (2014). A New Stock Rally Dawns in China. Wall Street Journal, December 5, C1\&C4.

Hong, Shen, \& Lingling Wei. (2015). China's Moves Fail to Tame Stock Market. Wall Street Journal, July 9, A1 \&A8.

Inoue, Tomoo, Pierre Lafaye de Micheaux, \& Jonathan Leightner. (2016). Several Related Methods of Estimating Total Derivatives that Capture the Influence of Omitted Variables. Manuscript.

Leightner, Jonathan E. (2002). The Changing Effectiveness of Key Policy Tools in Thailand. EADN Working Paper \# 19(2002) x0219-6417, Institute of Southeast Asian Studies for East Asian Development Network.

Leightner, Jonathan E. (2005a). Fight Deflation with Deflation, not with Monetary Policy. The Japanese Economy: Translations and Studies, 33(2), 67-93.

Leightner, Jonathan E. (2005b). The Productivity of Government Spending in Asia: 1983-2000. Journal of Productivity Analysis, 23, 33-46. https://doi.org/10.1007/s11123-004-8546-0

Leightner, Jonathan E. (2007). Omitted Variables, Confidence Intervals, and the Productivity of Exchange Rates. Pacific Economic Review, 12(1), 15-45. https://doi.org/10.1111/j.1468-0106.2007.00337.x

Leightner, Jonathan E. (2008). Omitted Variables and how the Chinese Yuan affects other Asian Currencies. International Journal of Contemporary Mathematical Sciences, 3(14), 645-666.

Leightner, Jonathan E. (2010a). China's Fiscal Stimulus Package for the Current International Crisis: What does 1996-2006 tell us?. Frontiers of Economics in China, 5(1), 1-24. https://doi.org/10.1007/s11459-010-0001-8

Leightner, Jonathan E. (2010b). How China's Holdings of Foreign Reserves Affect the Value of the US dollar in Europe and Asia. China \& World Economy, 18(3), 24-39. https://doi.org/10.1111/j.1749-124X.2010.01194.x

Leightner, Jonathan E. (2011a). Chinese Overtrading. In Steven Rosefielde, Masaaki Kuboniwa, and Satoshi Mizobata (Eds.), Two Asias: The Emerging Postcrisis Divide. Singapore: World Scientific Publishers. https://doi.org/10.1142/9789814366274_0011

Leightner, Jonathan E. (2011b). Fiscal Stimulus for the US in the Current Financial Crisis: What does 1930-2008 tell us? Applied Economic Letters, 18(6), 539-549. https://doi.org/10.1080/13504851003724374

Leightner, Jonathan E. (2013). The Diminishing Returns to Accumulating Foreign Reserves: Implications for China, the USA, and the World. China Economic Policy Review, 2(1), 25. https://doi.org/10.1142/S1793969013500040

Leightner, Jonathan E. (2015). The Limits of Fiscal, Monetary, and Trade Policies: International Comparisons and Solutions. Singapore: World Scientific.

Leightner, Jonathan E. (2017). Ethics, Efficiency, and Macroeconomics in China: From Mao to Xi. London: Routledge Press.

Leightner, Jonathan E., \& Tomoo Inoue. (2007). Tackling the Omitted Variables Problem without the Strong Assumptions of Proxies. European Journal of Operational Research, 178(3), 819-840. https://doi.org/10.1016/j.ejor.2006.02.022

Leightner, Jonathan E., \& Tomoo Inoue. (2008a). Capturing Climate's Effect on Pollution Abatement with an Improved Solution to the Omitted Variables Problem. European Journal of Operational Research, 191(2), 539-556. https://doi.org/10.1016/j.ejor.2007.08.009 
Leightner, Jonathan E., \& Tomoo Inoue. (2008b). The Effect of the Chinese Yuan on other Asian Currencies during the 1997-1998 Asian Crisis. International Journal of Economic Issues, 1(1), 11-24.

Leightner, Jonathan E., \& Tomoo Inoue. (2009). Negative Fiscal Multipliers Exceed Positive Multipliers during Japanese Deflation. Applied Economic Letters, 16(15), 1523-1527. https://doi.org/10.1080/13504850701578934

Leightner, Jonathan E., \& Tomoo Inoue. (2012a). Is China replacing the USA as an Engine for Global Growth?" International Economics \& Finance Journal, 7(1), 55-77.

Leightner, Jonathan E., \& Tomoo Inoue. (2012b). Solving the Omitted Variables Problem of Regression Analysis using the Relative Vertical Position of Observations. Advances in Decision Sciences. Rretrieved from http://www.hindawi.com/journals/ads/2012/728980/

Magnier, Mark, \& William Kazer. (2015). IMF Says Yuan is now Fairly Valued. Wall Street Journal, May 27, C3.

Mauldin, John. (2017, January 12). Chinese Currency Manipulation could become a Global Problem in 2017. Forbes.

Trivedi, Anjani. (2016). Did China Change the Way It Fixes the Yuan? Wall Street Journal, January 12, C3.

Trivedi, Anjani, \& Fiona Law. (2016). Beijing Steps in to Prop Up the Yuan. Wall Street Journal, January 13, $\mathrm{C} 1 \& \mathrm{C} 2$.

Vaishampayan, Saumya, \& Lingling Wei. (2016). Yuan Battle Goes to Hong Kong. Wall Street Journal, September $13, \mathrm{C} 1 \& \mathrm{C} 2$.

Wei, Gu, \& Chuin-Wei Yap. (2016). Yuan Crackdown Crimps Business. Wall Street Journal, March 9, A1\&A12.

Wei, Lingling. (2015). Beijing Puts Regulators at Center of Stock Probe. Wall Street Journal, December 18, A1\&A12.

Wei, Lingling. (2016). Beijing's Yuan Policy is Meant to Baffle. Wall Street Journal, January 15, C4.

Wei, Lingling. (2016). Beijing Moves to Slow Money Outflows. Wall Street Journal, January 28, A7.

Wei, Lingling. (2016). IMF wants more Data from Beijing on Yuan. Wall Street Journal, March 22, C1-C3.

Wei, Lingling. (2016). China Mulls New Capital Controls. Wall Street Journal, November 26-27, A1-A6.

Wei, Lingling. (2017). China Tested by Falling Reserves. Wall Street Journal, January 9, B1-B9.

Wei, Lingling, \& Anjani Trivedi. (2015). Beijing Struggles to Adjust Currency. Wall Street Journal, August 13, A1\&A7.

\section{Notes}

Note 1. Since the value of the US dollar is generally up for this time period, the fall in China's reserves could not be due to a fall in the value of the dollar.

Note 2. The $\alpha$ s and $\beta$ s are coefficients to be estimated, $\mathrm{Y}$ is the dependent variable, $\mathrm{X}$ is the explanatory variable, and $\mathrm{u}$ is random error.

Note 3. When the omitted variable made a thousand percent difference to the slope and random error was only one percent, then the VSGLS error to BD-RTPLS error ratio was 1.57 when 100 observations were used, 1.15 when 250 observations were used, and 0.68 when 500 observations were used. 